\title{
Reflections on China's Rural Collective Commercial Construction Land's Entry into Market
}

\author{
Zhiwei Liu \\ Zaozhuang University \\ Zaozhuang, Shandong, China 277160
}

\begin{abstract}
This paper explains relevant policies and analyzes the applicable conditions of these policies taking "Rural Collective Commercial Construction Land's Directly Entering into the Market" allowed by the Third Plenary Session of the 18th CPC Central Committee as the background, and makes further analysis on this "permission" from the perspective of theory and practice, namely, providing theoretical basis for the proposing of "permission" from the perspective of economic efficiency, property and cost in economics, the perspective of law and policy in science of law, and the perspective of structural function theory in sociology; further, introduces the practical basis for policy implementation through the success experience of "Nanhai Mode", "Kunshan Mode" and "Jiaxing Mode". This paper argues that the raising of this "permission" is not only "in time, suitable and appropriate", but also of milestone significance for solving the problems in the process of land system reform in our country.
\end{abstract}

Keywords-land system; collective construction land; element transfer; structural function theory

\section{INTRODUCTION}

Since the implementation of "the household contracted responsibility system" in rural after the reform and opening up, China's land reform has been in the groping forward: in 1982, the urban land was cleared to be owned by the state for the first time; the official separation of ownership and use right was proposed in 1988; "the land use right may be transferred according to law" and so on were stipulated in 1999. Although the use right and ownership was further detailed in each regulation, there is no fundamental change in the method of collective land's entering into market before the Third Plenary Session of the 18th CPC Central Committee, as land acquisition by government still is the only legal mode. That is to say, only convert the collective land to the state owned one through land acquisition by government, can the rural collective land be able to flow into the urban land market. The original intention of the state to implement such land system is to prevent farmers charge at random in the process of industrialization and urbanization, and to reduce the cost of industrialization and urbanization.

Fund project: Special research project of the technological innovation strategy by Ministry of Science and Technology of "Research on Role Positioning of Government in Rural S\&T Entrepreneurship and Influencing Factors", Project of Zaozhuang Federation of Social Science Circles (zz201401), Funds for Doctor of Zaozhuang University, and Scientific Research Funds at School-level (2014yy06).

CLC No.: F320.2 Document code: A

\section{POLICY INTERPRETATION}

In order to solve the problem of rural collective land transfer, the Third Plenary Session of the 17th CPC Central Committee has already toughed upon simply the issue of rural collective land's entering into land market. However, the breakthrough about collective land transfer did not appear in the session decision until the Third Plenary Session of the 17th CPC Central Committee. The "Decision on Major Issues Concerning Comprehensively Deepening Reforms of CPC Central Committee " (hereinafter referred to as the "Decision") puts forward that "under the premise of conforming to the planning and use control, the rural collective construction land is permitted to be transferred, leased and be invested, and it may enter into the market equally with the state owned land with the same right and the same price"(hereinafter referred to as the "Permission"). Thus the ear that rural collective land could not enter into the land market, and "although it is the same as state owned land, they have different rights and prices" was ended [1].

\section{THEORETICAL SUPPORT}

\section{A. Economic Theory Basis}

From the perspective of economic efficiency, the efficiency of a competitive market is greater than that of a monopolistic market. Previously, government gets the land through land expropriation by means of "Buyer's Monopoly", and converts the collective land to the state owned land, then, transfers the land that has been acquired to urban land market through the methods of allocation, agreement and transfer by means of "Seller's Monopoly", which is a typical single channel land circulation. And it results in that the real market price of land cannot be reflected by the actual price of rural collective land transfer, land resource configuration and flow is inefficient. The Permission proposed in Decision of the Third Plenary Session has broken the previous mode of single channel land transfer, permitting the rural collective construction land to be transferred, leased and invested, and to enter into land market equally to the state-owned land, with the same right and price. Such multi-channel land supplying mode is able to adapt to the market economy environment easier that single channel land supplying mode, and can absorb relevant information more sensitively, reflect the relative scarce degree of land in the market, and provide the foundation for effective allocation of land resources [2]. 
From the perspective of cost, the elements of a lower cost can make the enterprise gain more profit, which is beneficial to development and improvement of enterprises. Previously, if an enterprise wants to obtain land, it need to negotiate with local government, and pay price required by the local government, to get use right of "state-owned land" that has been acquired by the government in certain fixed number of years. This single land supplying channel is not sensitive to reflect the market price of land, and the useful life is fixed, even need to pay a certain compensation of land expropriation. Therefore, when the enterprise obtains the state-owned land use rights, it usually needs to pay a high transaction cost which originally is not a must.

\section{B. Legal Theory Basis}

Under the condition of modern market economy, the contents of the policies and regulations purpose include maintaining market economic order, preventing and eliminating the gross imbalance and structural imbalance in the economic operation, optimizing resource allocation, and promoting the economic development and social progress, in order to realize the coordinated development of the interests of the subject of law [3]. The "Permission" proposed in "Decision" complies with the above purposes fully. Currently, China still faces such stresses as the expansion of income gap between urban and rural areas, unreasonable resource allocation between urban and rural areas and uncoordinated economic and social development in urban and rural areas.

Article 10 of the Constitution of China stipulates that: "In order to meet the demands of public interest, the state may conduct collection or requisition of the land and make compensation in accordance with the law." Clause 4 of Article 2 of the Land Administration Law stipulates that: "In order to meet the demands of public interest, the state may conduct requisition of the collective land in accordance with the law." Article 42 of Property Law also stipulates that: "In order to meet the demands of the public interest, the collective land and the houses and other real estate belonging to individual and unit may be requisitioned in accordance with the limits and procedures as prescribed by law". It can be seen that the right for collective land to enter into market directly is not expressly stipulated in current laws. To strengthen the operability of "Permission" proposed in the "Decision", and to ensure the vital interests of the parities involving in land transfer, there is no time to delay the modification and perfection of current laws and regulations [4].

\section{Sociology Basis}

In the structural-functional theory school of sociology, the abstract functionalism put forward in Parsons' AGIL model believes that "any action system (group and organization) that want to survive in the society must have four basic functions, namely, adaptive function (A), target realizing function $(\mathrm{G})$, integration function (I) and dimensional module function (L)" [5], and to meet the four functions, it is necessary to make economic system satisfy the adaptive function of social system. The current land system reform is the very process of adjusting economic system to satisfy social system's adaptive function.
In addition, the land that is allowed to enter into market in "Decision" is the "rural collective construction land for commercial purpose" only not all the rural collective construction land, and not all the rural collective land; the socalled "permitted to enter into market" as specified in the regulations shall also be conducted on the premise of "meeting planning and use control", which is the decision after considering the global society comprehensively. From past reform experience, the reform conducted gradually is more suitable for China's national condition, which is closer to the "Pareto improvement" or "Kaldor Improvement", having the orderliness and irreversibility in terms internal logic, which is conducive to maintain balance between speed and stability in the process of reform [6]. And the friction cost of reform is an increasing function of reform's radical degree. In the context that relevant laws and regulations haven't been perfected and the unified urban and rural construction land market has not yet fully established, take the rural collective construction land for commercial purpose as an entry point, is a proper approach to reduce social costs of reform, and avoid large scale social instability and wasting of resources [7].

\section{PRACTICE BASIS}

Most of the gradually advanced reforms in China are not directly carried out across the country at the same time, but to make pilot of each policy and measure in a small area, and promote locally after getting the corresponding achievements and the summary is made. Promote the reform via a local and experimental way, may disperse the cost of fail pilot and avoid too much mistakes. Over the past 20 years, many mode of collective land's entering into market has been formed in the process of exploring rural collective construction land's entering into market in the pilot areas. The famous ones include "Nanhai Mode", "Kunshan Mode", "Jiaxing Mode", "Wuhu Mode", and "Chengdu Mode" and so on. This paper introduces the exploration of rural collective land's entry into market in the pilot areas taking the first three modes as examples.

\section{A. Nanhai Mode}

Nanhai City started to put the land shareholding system into trial use in 1992, namely to take the administrative villages or villagers' groups as unit, split the collective property and collective land into shares to establish sharecooperative organization together. Then the land will be leased directly by the share-cooperative organization or be leased after the workshops are constructed, and the farmers within village will share incremental benefits earned from land use right transfer. Thus, collective land is converted to construction land directly without land acquisition. The formalities are simple for foreign enterprises to rent collective land relative to the state owned land, and collective construction land can be lease both for long term and short term, to meet different land demands. By 2002, the land for industrial purpose in Nanhai will be up to a total of $150000 \mathrm{mu}$, among which, the land that is kept collectively closes to $50 \%$, or $73000 \mathrm{mu}$.

The experience of Nanshai Mode can be summarized as: first, the cost for industrial development purpose will be 
reduced effectively through transferring collective land directly to the industrial use, having positive significance to the new industrialization strategy. Second, land value-added benefits can be obtained which is different from the governmental land acquisition, and will be shared according to the equity related farmers. Third, farmers obtain the right to derive benefits from land in land's non-agricultural propose by way of share dividend, increasing farmers' property income.

\section{B. Kunshan Mode}

In Kunshan mode, the village collective obtains some "quota" of non-agricultural land in the form of reclamation first of all, then conducts "bid inviting" publicly among farmers within this village, and the cooperative economy organizations founded by farmers will conduct rent-seeking for the construction of workshop or other commercial and industrial facilities, then leased to foreign industrial and commercial enterprises, and share the benefits brought by agricultural land transfer by way of collecting rent. The unique feature of Kunshan Mode is "land reclamation", increasing the non-agricultural land without reducing agricultural land; Kunshan leases the non-agricultural construction land by way of public bidding in the village, and establish cooperative organization according to the wishes of farmers, without forcing farmers to participate in, and bring quite large expected return for the farmers who have participated in; what's more, the conversion of the land's transfer right from totally belonging to the village collective to partly owned by the organizations that have signed contract, has resulted in the partly loss of land rights and interests.

\section{Jiaxing Mode}

Jiaxing City of Zhejiang Province starts with "two separates and two change", and explores reform practice of system linkage [8], which mainly involves: separate residential land from the contracted land; separate demolition from land adjustment; promote incentive operation and change the mode of agricultural production through converting contracted land to security, equity and rent; promote centralized residence and improve farmer's living style by way of converting residential land to money, house and places. In specific operation process, take the town as an unit and make the farmers voluntarily apply for giving up the contracting right to rural land and convert to rural residence on the basis of formulating rural construction planning and land use planning; the transfer of contracting right to rural land includes a variety of forms, as the shares can be bought using the right to use (name convert to shares), and the right to use can also be leased back by the collective (namely convert to rent); the local government will provide social security equal to urban residents for the farmers who give up contract voluntarily; after a review of the original housing, farmers may apply to replace the residential site with urban settlement building or move to the central village; the registered residence of the farmers who have moved to the town and are willing to give up the contract right of collective agricultural land may be converted to urban registered residence, and promote the modernization of living style; after comprehensive sorting, the rural collective land (including village) may be divided into various agricultural functional zones, and attract investment uniformly, thus to promote the modernization of agricultural production mode.

In short, the Nanhai Mode and Kunshan Mode belong to the exploration of collective construction land's direct entry into market, while Jiaxing Mode further involves the replacement and conversion of rural residential land and contracted land. On the one hand, this shows that our country has mastered certain pilot experience about rural collective land's direct entry into market, and there are practice mode to be sought for nationwide promotion; on the other hand, not only the experiment of rural collective construction land's entry into market is conducted in pilot area, but the exploration of rural residential land and contracted land's transfer is conducted in the pilot area.

In addition, it can be found from the local policies and regulations that, not only the pilot area has explored the collective land's direct entry into market, relevant local policies and regulations have also been introduced directly to support the transfer of collective construction land use rights. Among them, the first one that has issued relevant documents is still Guangdong province, our reform pioneer. In 2005, Guangdong province issued and implemented the Administrative Measures of Collective Construction Land's Transfer in Guangdong Province, which stipulates that the collective construction land use rights may be sold, leased, transferred, sublet or mortgaged. Other provinces such as Jiangsu, Hainan, Hebei etc., and cities such as Dongguan, Wuhu, and Chengdu and so on also have related specific policy document to support the transfer of collective construction land use rights. This suggests that state has already grasped certain practical experience about collective construction land use rights transfer in terms of specific policies and regulations, and the national administrative measures at macro level is also expected to be issued.

\section{CONCLUSION}

This paper has discussed the decision with breakthrough significance of "under the premise of conforming to the planning and use control, the rural collective construction land is permitted to be transferred, leased and be invested, and it may enter into the market equally with the state owned land with the same right and the same price" as proposed on the Third Plenary Session of the 18th CPC Central Committee from the perspective of theory and practice. Taking the current situation introduction and policy interpretation as the starting point, this paper has explained the timeliness and limitation of this "Permission"; explained the policy's rationality and applicability from the perspective of economics, law and sociology; at last, emphasized that this breakthrough decision not only have theoretical basis, but also have rich practical basis and operation experience by introducing the typical pilot experience. Facing the great pressure of land system reform of current socialist market economy, the "Permission" put forward in the Third Plenary Session is not a dramatic measure to solve all the land problems, but relaxed the restrictions on rural collective land's direct entry into market in a fundamental way. Although it is only a policy direction guide, and specific measures and standards are not perfect, it has found the key of land system reform of market economy, to fundamentally 
solve basic problems of rural collective land's transfer along with the market orientation.

\section{REFERENCES}

[1] Feng Hua, Chen Renze. Rural Land System Reform without Baseline Breakthrough [N].People's Daily,2013-12-7.

[2] Zhou Qiren. Agricultural Land Property and Land Requisition System--Major Choice Faced by China's Urbanization [J], Economics (Quarterly), 2004(4): 193-210

[3] Yang Zixuan, Xu Jie. Science of Economic Law [M]. Beijing: Peking University Press, 2012.

[4] Hu Liling. Current Legal Situation, Problems and Approaches of Rural Collective Construction Land Transfer [J]. Journal of Social Science of Hunan Normal University, 2010(2): 15-18.

[5] Xiao Yunzhong. Introduction to Sociololgy [M].Beijing: Tsinghua University Press, 2012.

[6] Li Yifu, Cai Fang and Li Zhou. Chinese Miracle: Development Strategy and economic reform $[\mathrm{M}]$. Shanghai: Shanghai People's Publishing House, 2002.

[7] Fan Gang. Two Kinds of Reform Cost and Two Types of Reforms [J]. Economic Research Journal,1993(1): 3-15.

[8] Soft Science Committee Office of Ministry of Agriculture. Integration of Urban-Rural Development and Rural Public Service [M]. Beijing: China Financial \& Economic Publishing Housing, 2013. 